\title{
Impact of global climate change on stream low flows: A case study of the great Miami river watershed, Ohio, USA
}

\author{
Sabin Shrestha ${ }^{1}$, Suresh Sharma ${ }^{1 *}$, Rishabh Gupta ${ }^{2}$, Rabin Bhattarai ${ }^{2}$ \\ (1. Civil and Environmental Program, Youngstown State University, Youngstown, OH 44555, USA; \\ 2. Department of Agricultural and Biological Engineering, University of Illinois at Urbana-Champaign, Urbana, IL 61801, USA)
}

\begin{abstract}
Climate change will profoundly affect hydrological processes at various temporal and spatial scales. This study is focused on assessing the alteration of water resources availability and low flows frequencies driven by changing climates in different time periods of the $21^{\text {st }}$ century. This study evaluates the adaptability of prevailing Global Circulation Models (GCMs) on a particular watershed through streamflow regimes. This analysis was conducted in the Great Miami River Watershed, Ohio by analyzing historical and future simulated streamflow using 10 climate model outputs and the Soil and Water Assessment Tool (SWAT). The climate change scenarios, consisting of ten downscaled Coupled Model Intercomparision Project Phase 5 (CMIP5) climate models in combination with two Representative Concentration Pathways (RCP 4.5 and RCP 8.5) were selected based on the correlation between observed records and model outputs. Streamflow for three future periods, 2016-2043, 2044-2071 and 2072-2099, were independently analyzed and compared with the baseline period (1988-2015). Results from the average of ten models projected that 7-day low flows in the watershed would increase by $19 \%$ in the $21^{\text {st }}$ century under both RCPs. This trend was also consistent for both hydrological (7Q10, 1Q10) and biological low flow statistics (4B3, 1B3). Similarly, average annual flow and monthly flows would also increase in future periods, especially in the summer. The flows simulated by SWAT in response to the majority of climate model projections showed a consistent increase in low flow patterns. However, the flow estimates using the Max-Planck-Institute Earth System Model (MPI-ESM-LR) climate output resulted in the biological based low flows (4B3, 1B3) decreasing by $22.5 \%$ and $33.4 \%$ under RCP 4.5 and $56.9 \%$ and $63.7 \%$ under RCP 8.5 , respectively, in the future when compared to the baseline period Regardless, the low flow ensemble from the 10 climate models for the $21^{\text {st }}$ century seemed to be slightly higher than that of historical low flows.
\end{abstract}

Keywords: climate change, low flows, SWAT, climate models, Great Miami River Watershed

DOI: $10.25165 /$ j.ijabe.20191201.4486

Citation: Shrestha S, Sharma S, Gupta R, Bhattarai R. Impact of global climate change on stream low flows: A case study of the great Miami river watershed, Ohio, USA. Int J Agric \& Biol Eng, 2019; 12(1): 84-95.

\section{Introduction}

Stream water quality parameters like dissolved oxygen ${ }^{[1]}$, nutrient concentration and the quality of the aquatic habitat ${ }^{[2]}$ are greatly affected by low-flow conditions. Moreover, stream low flows may have detrimental implications on water supply, power generation, navigation and waste load allocation ${ }^{[3-5]}$. Therefore, understanding of low-flow events and corresponding effects on river ecosystems are essential for effective and sustainable water resource management ${ }^{[6]}$. Many factors including soil infiltration, watershed hydraulics, topography, vegetation type, evapotranspiration rates and local climatic conditions have an influence on low flows regimes ${ }^{[7]}$. Likewise, anthropogenic

Received date: $2018-06-26$ Accepted date: 2019-01-13

Biographies: Sabin Shrestha, Former Graduate student, research interests: climate change and its hydrological impacts, stream flow forecasting, Email: sshrestha01@student.ysu.edu; Rishabh Gupta, Graduate student, research interests: large scale crop modeling, climate change impact studies Email: rishabh7@illinois.edu; Rabin Bhattarai, Assistant Professor, research interests: climate-water-food nexus modeling, erosion and sediment control, Email: rbhatta2@illinois.edu.

*Corresponding author: Suresh Sharma, research interests: watershed modeling, climate change impacts on water resources, flood forecasting, One University plaza, Youngstown State University, Youngstown, OH 44555, USA. Tel: +330-941-1741, Fax: +330-941-3265, Email: ssharma06@ysu.edu. activities may alter those factors and potentially influence the low-flow conditions in streams.

Future climate change may lead to a more intensifying hydrological cycle processes ${ }^{[8]}$ including an increased variation in precipitation ${ }^{[9]}$, change in evaporation rates ${ }^{[10]}$ and earlier snowmelt The Fifth Assessment Report (AR5) of the Intergovernmental Panel on Climate Change ${ }^{[11]}$ has estimated an increase in global average temperature based on different emission scenarios over the $21^{\text {st }}$ century. An increase in global temperature will enhance the rate of evapotranspiration and speed up water cycle ${ }^{[12]}$. As a result, an uneven distribution of moisture in the atmosphere would take place leading to heavy precipitation in one region and extreme drought in the other ${ }^{[13]}$.

Many studies have been conducted to comprehend streamflow variability due to climate change ${ }^{[14-22]}$. Global Circulation Models (GCMs) are powerful tools for climate simulation and impact assessment under different warming scenarios ${ }^{[23]}$. Several climate models have been developed based on a variety of numerical techniques and parameterizations. However, many systematic biases could be present across the set of models when compared against past and present-day climate conditions ${ }^{[24,25]}$. These biases vary considerably from one model to another and generally limit the strengths and weaknesses of a simulation. Therefore, it is crucial to validate the applicability of those climate model outputs before applying them for regional hydrological impact 
analysis $^{[26]}$. In addition, it is essential to use various GCMS to quantify projection uncertainty.

Mixed results have been reported in the global literature regarding the impacts of climate change on low flows, with some studies reporting an increase in low flows ${ }^{[27-31]}$ whereas other studies have predicted a decrease in low flows ${ }^{[32-38]}$. For example, Mozayyan et al. ${ }^{[39]}$ conducted a climate change impact study on low flows in Iran based on the $\mathrm{A}^{[40]}$ emission scenario and reported that minimum 7-day low flow with various return periods would be relatively higher compared to the baseline period in all subwatersheds. Similarly, Tian et al. ${ }^{[1]}$ conducted modeling studies for the Xiangjiang River Basin China and reported the increase in seven-day low flows in the future with various return periods. Laaha et al. ${ }^{[42]}$ conducted a climate change study in Central Austria, which represented the European continent, and reported consistent future increases in low flows for the watershed.

Similarly, Mahmood et al. ${ }^{[33]}$ conducted a study in Pakistan using the HADCM3 model under both the $\mathrm{A} 2$ and $\mathrm{B} 2^{[40]}$ scenarios and reported that low flows would decrease in the future. Cervi et al. ${ }^{[34]}$ reported that $7 \mathrm{Q} 10$ (seven days low flows with 10-year recurrence interval) would decrease by $25 \%$ in the future in the Italian Northern Apennines. Similarly, Kay et al. ${ }^{[43]}$ conducted the climate change impact assessment across the Great Britain and reported that the low flows would decrease, especially in the later time period. Marx et al. ${ }^{[35]}$ conducted a climate change impact study in Europe for future warming scenarios of $1.5^{\circ} \mathrm{C}, 2^{\circ} \mathrm{C}$ and $3{ }^{\circ} \mathrm{C}$ and reported that low flows would decrease from $12 \%$ to $35 \%$ and this decreasing rate would be much higher under $\mathrm{RCP} 8^{[44,45]}$ due to projected decrease in precipitation. Likewise, Kreye et al. ${ }^{[36]}$ reported a substantial decrease of low flow for the near and far future under the A1B emission scenario. Similarly, Stumbaugh $^{[37]}$ projected that future low-flows in Skagit River Basin Canada would decrease by 5\%-20\%. Dang et al. ${ }^{[38]}$ conducted a study in central Vietnam using various GCMs and regional models and reported decreased low flows due to future climate change.

In addition, several climate change studies have been conducted using the widely applied Soil and Water Assessment Tool (SWAT) ecohydrological model ${ }^{[46]}$ in conjunction with climate model output for low flow prediction. For example, Zuo et al. ${ }^{[47]}$ conducted a study using SWAT for the Wei River basin in China and reported that lows flow would be lower in the future. Babur et al ${ }^{[48]}$ conducted a study in Pakistan using SWAT under RCP 4.5 and $8.5^{[44,45]}$ future climate scenarios and reported that low flows would increase in the future. Similarly, Mohammed et al. ${ }^{[49]}$ conducted a study for the Brahmaputra River basin using several GCM outputs to drive SWAT and found that low flows (hydrological droughts) would be a serious concern for Bangladesh in future. Eisner et al. ${ }^{[50]}$ conducted a study in a set of eleven representative large river basins across the world using nine regional hydrological models including SWAT and reported that low flows would decrease in the future. However, $\mathrm{Xu}$ et al. ${ }^{[51]}$ conducted a study in China using SWAT and various GCM projections in conjunction with the $\mathrm{A} \mathrm{B}^{[40]}$ scenario and reported an increase in low flows in the future. Similarly, Piniewski et al. ${ }^{[52]}$ conducted a climate change study for the Odra basin in Europe using SWAT and reported an increase in low flows during the late $21^{\text {st }}$ century. Leta et al. ${ }^{[53]}$ conducted a study using SWAT for selected Pacific Island watersheds and reported that future extreme low flows would increase by $60 \%$ compared to the baseline period. Overall, the current literature presents mixed results regarding the impact of climate change on future extreme low flows.

The majority of low flow studies that has been conducted in the past are based on previously established GCMs, derived from simulation of climate models participating in phase three of the Coupled Model Inter-comparison Project (CMIP3) ${ }^{[37,54]}$. In addition, an extensive analysis for stream low flow indices was not carried out using various climate models' outputs. Low-flow conditions in streams could be better understood considering recent climate models and emission scenarios ${ }^{[55]}$. Also, it has been reported that hydrologic simulations from phase 5 (CMIP5) inputs depict wetter conditions than simulations based on CMIP3 inputs $^{[56]}$. Therefore, in this study, CMIP5 model outputs and updated greenhouse gas emission scenarios were used to assess the impacts of climate change on stream low flows in the Great Miami River watershed in southwestern part of Ohio. The Great Miami River watershed is a subbasin of Ohio River basin, which receives drainage from both the little and Great Miami Rivers (Figure 1).

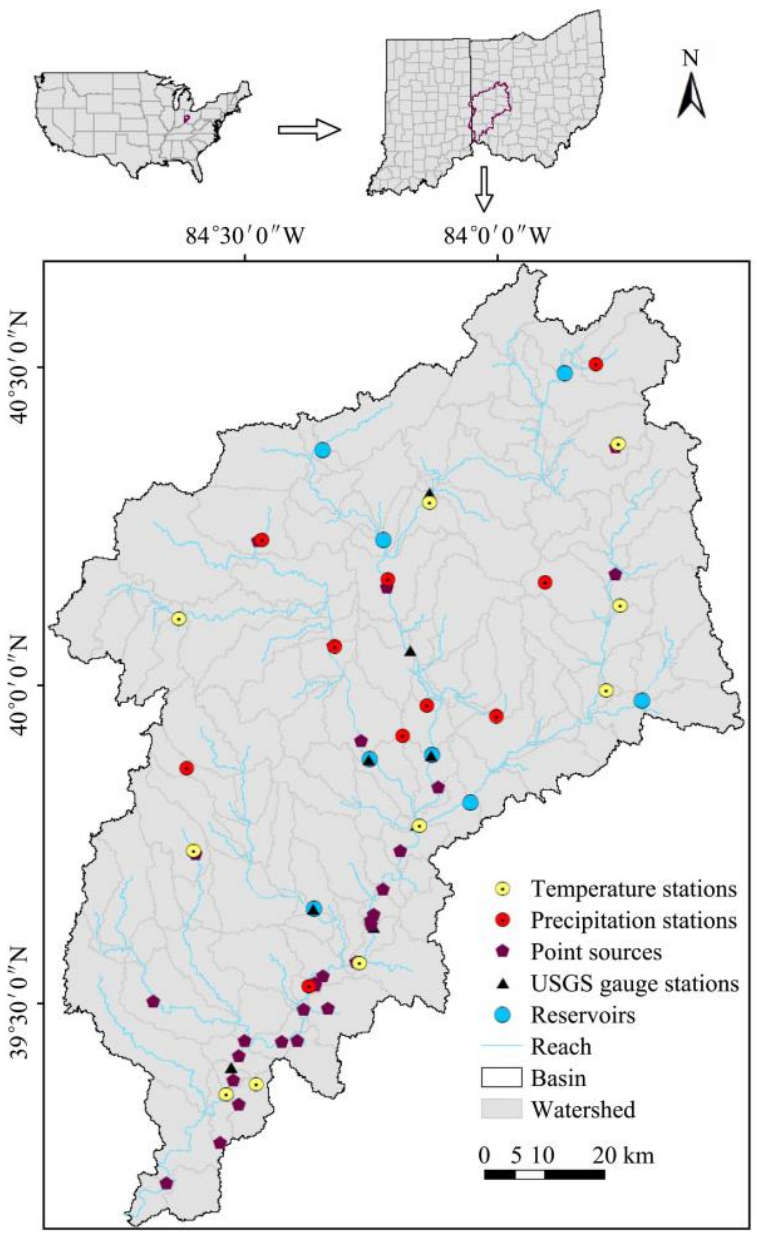

Figure 1 Study area of Great Miami River watershed consisting sub-watersheds, gage stations, climate stations, location of point sources and reservoirs

Since an appropriate hydrologic model is equally necessary to link climate change outputs and water yields (daily discharge) in the watershed ${ }^{[57]}$, SWAT was utilized for this analysis. Therefore, the specific objectives of this study are: i) to assess the impact of future climate change on low flows using SWAT model with CMIP5 model outputs; ii) to compute various hydrological and biological low flow indices at the outlet of the watershed and compare them between historical and future periods. 


\section{Materials and methods}

\subsection{Climate Projections}

In recent years, climate projection data have been derived from the fifth phase of the CMIP5 ${ }^{[58]}$, which has incorporated new GCMs and have been widely used for climate change impact analysis ${ }^{[59]}$. These newly disseminated models have more comprehensive greenhouse-gas emission scenarios and have been downscaled to finer spatial resolution, $1 / 8^{\circ}$ latitude-longitude or $12 \mathrm{~km}$ by $12 \mathrm{~km}^{[58]}$. The impact assessments using these models provide acceptable results compared to other methods ${ }^{[60]}$ even though uncertainty in the models exists ${ }^{[61]}$.

Based on the greenhouse gas emissions including mitigation measures, atmospheric concentration of air pollutants and land use, four different Representative Concentration Pathways (RCPs), namely RCP 2.6, RCP 4.5, RCP 6.0 and RCP 8.5, were constructed to help researchers assess impacts of climate change ${ }^{[44,45]}$. Among the four scenarios, RCP 2.6 is the most stringent mitigation scenario that aims to balance the global warming below $2{ }^{\circ} \mathrm{C}$ above the pre-industrial temperature (before 1750). RCP 8.5 is a scenario with high greenhouse gas emissions that could be the result of no substantial efforts to limit emissions, whereas RCP 4.5 and RCP 6.0 are two intermediate scenarios ${ }^{[11]}$.

\subsection{Study area}

The Great Miami River watershed is located in the southwestern part of Ohio, USA (Figure 1). The watershed covers an area of $10023.25 \mathrm{~km}^{2}$, includes 15 Ohio counties and four Indiana counties, and consists of an approximate maximum width of 113 kilometers and length of 193 kilometers. The watershed lies between latitudes $39^{\circ} 8^{\prime} 43.67^{\prime \prime} \mathrm{N}$ to $40^{\circ} 38^{\prime} 28.27^{\prime \prime} \mathrm{N}$ and longitudes $83^{\circ} 33^{\prime} 0.67^{\prime \prime} \mathrm{W}$ to $84^{\circ} 54^{\prime} 25.77^{\prime \prime} \mathrm{W}$. Similarly, the altitude of the watershed varies from $151 \mathrm{~m}$ in the south to $1545 \mathrm{~m}$ in the north, having a mean altitude of $299 \mathrm{~m}$.

The distribution of land use in this watershed includes agriculture (70\%), residential, commercial and industrial (18\%), forests $(11 \%)$, and water bodies and wetlands (1\%) (Table 1). Major wastewater treatment facilities and industries are located along the downstream reaches of the Great Miami River (Figure 1), thus compromising the water quality of the river during the dry periods.

Table 1 Percentage of Land cover in GMR watershed

\begin{tabular}{lc}
\hline \multicolumn{1}{c}{ Land Cover } & Percentage/\% \\
\hline Open Water & 1.4 \\
Developed, Open Space & 6.0 \\
Developed, Low Intensity & 3.2 \\
Developed, Medium Intensity & 1.1 \\
Developed, High Intensity & 0.5 \\
Barren Land & 0.1 \\
Deciduous Forest & 21.9 \\
Evergreen Forest & 0.6 \\
Mixed Forest & 0.1 \\
Shrub/Scrub & 0.3 \\
Herbaceous & 1.5 \\
Hay/Pasture & 7.3 \\
Cultivated Crops & 54.6 \\
Woody Wetlands & 1.3 \\
Emergent Herbaceous Wetlands & 0.2 \\
\hline
\end{tabular}

The Great Miami River has four major river sub-watersheds: Upper Great Miami, Mad River, Stillwater River, and Lower Great
Miami River. Highly productive sand and gravel aquifers, known as buried valley aquifers, are the main features of the watershed. These aquifers are the primary source of groundwater for adjoining river channels. As a result, some of the rivers in the watershed are able to sustain flow even during periods of prolonged drought ${ }^{[62]}$.

\subsection{SWAT model}

The SWAT model consists of two parts: (1) land phase of the hydrological cycle, and (2) routing of runoff through the reaches. Land phase modeling is done by partitioning a river watershed into multiple sub-watersheds that are composed of one or several Hydrological Response Unites (HRUs); an area of relatively homogeneous land use/land cover, soil types, and slopes. Calculation of water balance is subsequently accomplished for additional HRUs within each sub-watershed. In SWAT, different sub-watershed outlets are connected by stream networks and routing phase determines the flow of water through the network ${ }^{[63]}$. In SWAT, the water loss from the system can be computed through various methods including Penman-Monteith, Priestley-Taylor and the Hargreaves method ${ }^{[63]}$. In this study, Penman-Monteith method was selected, which utilized solar radiation, air temperature, relative humidity and wind speed to compute potential evapotranspiration.

The SWAT model uses either the Curve Number $(\mathrm{CN})$ method or Green and Ampt infiltration method to calculate the total volume of runoff. While the $\mathrm{CN}$ method is lumped over time and used when precipitation data are provided in daily time steps ${ }^{[64]}$, the Green and Ampt method requires input data at a sub-daily time resolution ${ }^{[63]}$. In this study, $\mathrm{CN}$ method was selected, which utilized cumulative precipitation and $\mathrm{CN}$ for sub watershed derived from the unique combination of land use and hydrological soil group to compute runoff. In order to compute runoff, the model computes initial abstraction as $20 \%$ of potential retention, which is estimated based on CN. The streamflow simulation and routing is carried out on a daily scale. Finally, the surface runoff is converted into daily stream flow using the area of the watershed, unit peak discharge and pond or swamp adjustment factor.

SWAT consists of a large number of parameters that describe various hydrological conditions and characteristics across the watershed. These parameters are necessary for calibration and validation to improve the model performance ${ }^{[63]}$.

\subsection{SWAT model inputs}

The data required for the SWAT modeling are Digital Elevation Model (DEM), land use, soil and climate data, as well as reservoir and point source information. A DEM contains all the information about watershed terrain and streams networks. A $30 \mathrm{~m}$ DEM resolution for the study area was obtained from the USGS National Elevation Dataset ${ }^{[65]}$. The DEM was utilized to delineate the watershed and create 144 sub-watersheds. Similarly, the most recently available land use dataset (2011), which has a spatial resolution of $30 \mathrm{~m}$, was acquired from the National Land Cover Dataset ${ }^{[66]}$. The distribution of land use in the watershed is presented in Table 1. State Soil Geographic (STATSGO) and Soil Survey Geographic (SSURGO) are the two most commonly used soil databases ${ }^{[67]}$. The STATSGO data was used in this study due to relatively large size of the watershed and the extremely detailed characteristics of the SSURGO data. As the hydrological processes are quantified in a small entity known as hydrologic response unit (HRU), the threshold values of 5\%, 15\% and $15 \%$ for land use, soil and slope respectively were used to create 2676 HRUs to improve computational efficiency of simulations.

Climate data including precipitation, temperature, solar 
radiation, wind speed and relative humidity are essential for hydrological modeling. The SWAT model requires either user-defined weather data or simulated data from an inbuilt weather generator $^{[68]}$. In this study, historical weather datasets including precipitation, maximum and minimum temperature were downloaded from the National Climatic Data Center (NCDC) ${ }^{[69]}$. Nineteen precipitation stations and 10 temperature stations with continuous daily records for 36 years (1980-2015) were available for the watershed (Figure 1). However, the rest of the climate data were simulated utilizing the weather generator tool in the SWAT model. Since reservoirs and dams are used for water storage and flood control, three major reservoirs and five big dams were incorporated into the model during the watershed delineation process as shown in Figure 1. Information and data regarding reservoirs and dams, obtained from Miami Conservancy District and the United States Army Corps of Engineers (USACE), are presented in Table 2 . In addition, 28 major point sources including industries and wastewater treatment facilities having effluent greater than $2273 \mathrm{~m}^{3} / \mathrm{d}$ were downloaded from the
Environmental Protection Agency (OEPA $)^{[70]}$ and incorporated in the model structure (Figure 1).

\subsection{Model setup, calibration, and validation}

SWAT was set up and run from 1988 to 2015 in daily time steps using a 3-year warm up period (1985-1987). The model was calibrated by using observed streamflow for a 10-year period from 2005 to 2014 at nine USGS gage locations within the watershed (Figure 1). Both manual and automatic parameter optimization procedures were utilized in the model calibration to fine-tune the calibration parameters. The multi-site SWAT model calibration and sensitivity analysis were performed using the automated SWAT Calibration and Uncertainty Program (SWAT-CUP) ${ }^{[71]}$. In SWAT-CUP, a semi-automatic inverse modeling procedure algorithm, known as Sequential Uncertainty Fitting version 2 (SUFI-2) was selected to find the most favorable model parameters. Twenty different parameters, as shown in Table 3, were selected based on a similar past study ${ }^{[72]}$. These model parameters were then independently validated by using observed streamflow data from 1995 to 2004 in the respective locations.

Table 2 Major reservoirs and dams in watershed

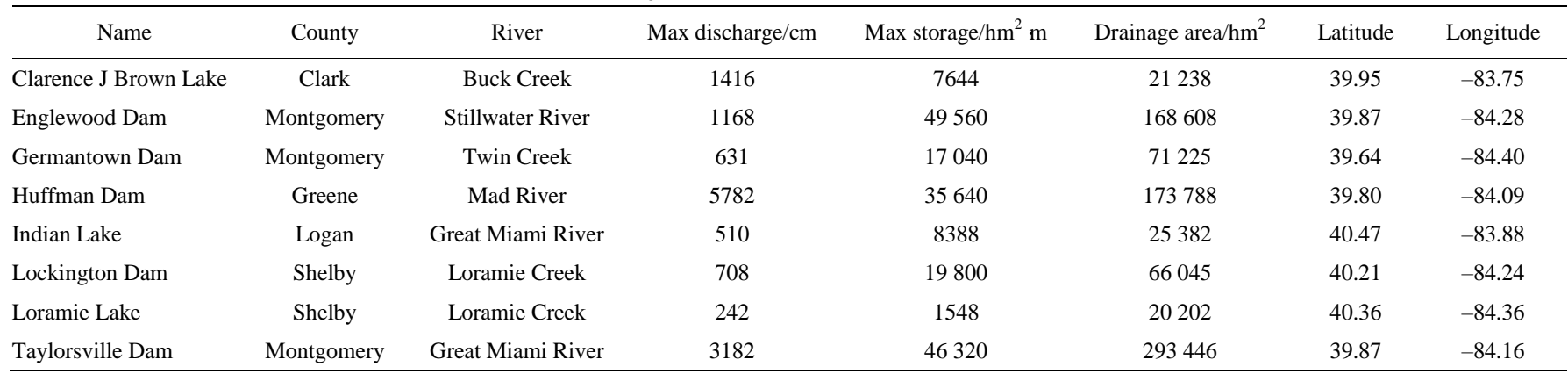

Table 3 Model parameters used in the SWAT calibration

\begin{tabular}{|c|c|c|}
\hline Parameters & Range & Calibrated value \\
\hline Available water capacity of the soil layer $/ \mathrm{mm} \cdot \mathrm{mm}^{-1}$ & $0-1$ & $0.13-0.23$ \\
\hline Base flow alpha factor/d & $0.1-1$ & 0.86 \\
\hline Base flow alpha factor for bank storage & $0-1$ & 0.97 \\
\hline Deep aquifer percolation fraction & $0-1$ & 0.43 \\
\hline $\begin{array}{l}\text { Effective hydraulic conductivity in main channel } \\
\text { alluvium } / \mathrm{mm} \cdot \mathrm{h}^{-1}\end{array}$ & $0.025-500$ & 127.63 \\
\hline Groundwater "revap" coefficient & $0.02-0.20$ & 0.04 \\
\hline Groundwater delay/d & $0-500$ & 74.04 \\
\hline Manning's " $n$ " value for the main channel & $0-0.15$ & 0.06 \\
\hline $\begin{array}{l}\text { Maximum melt rate for snow during year (occurs } \\
\text { on summer solstice) } / \mathrm{mm} \cdot{ }^{\circ} \mathrm{C}^{-1} \cdot \mathrm{d}^{-1}\end{array}$ & $0-10$ & 0.71 \\
\hline $\begin{array}{l}\text { Minimum melt rate for snow during the year } \\
\text { (occurs on winter solstice) } / \mathrm{mm} \cdot{ }^{\circ} \mathrm{C}^{-1} \cdot \mathrm{d}^{-1}\end{array}$ & $0-10$ & 0.81 \\
\hline Plant uptake compensation factor & $0.01-1$ & 0.86 \\
\hline Saturated hydraulic conductivity $/ \mathrm{mm} \cdot \mathrm{h}^{-1}$ & $0-2000$ & $3.8-37.8$ \\
\hline SCS runoff curve number & $39-98$ & $56.7-94.8$ \\
\hline Snow melt base temperature $/{ }^{\circ} \mathrm{C}$ & $(-5)-5$ & 0.13 \\
\hline Snow pack temperature lag factor & $0-1$ & 0.78 \\
\hline Snowfall temperature $/{ }^{\circ} \mathrm{C}$ & $(-5)-5$ & 0.05 \\
\hline Soil evaporation compensation factor & $0-1$ & 0.81 \\
\hline Surface runoff lag coefficient & $0.5-10$ & 2 \\
\hline $\begin{array}{l}\text { Threshold depth of water in shallow aquifer for } \\
\text { return flow to occur } / \mathrm{mm}\end{array}$ & $0-3000$ & 1004.4 \\
\hline $\begin{array}{l}\text { Threshold depth of water in the shallow aquifer for } \\
\text { revap to occur/mm }\end{array}$ & $0-500$ & 285 \\
\hline
\end{tabular}

\subsection{Model evaluation criteria}

The performance of the SWAT model was evaluated by using four statistical indicators: Nash-Sutcliffe Efficiency (NSE), Percentage Bias (PBIAS), Coefficient of Determination $\left(R^{2}\right)$ and the Ratio of Root Mean Square Error to the Standard Deviation (RSR). These indicators are mathematically represented by the following Equation (1) to Equation (4).

$$
\mathrm{NSE}=1-\left[\frac{\sum_{i=1}^{n}\left(Y_{i}^{\text {obs }}-Y_{i}^{\text {sim }}\right)^{2}}{\sum_{i=1}^{n}\left(Y_{i}^{\text {obs }}-Y_{i}^{\text {mean }}\right)^{2}}\right]
$$

$$
R^{2}=\left(\frac{\sum_{i=1}^{n}\left(Y_{i}^{\text {obs }}-Y_{\text {obs }}^{\text {mean }}\right)\left(Y_{i}^{\text {sim }}-Y_{\text {sim }}^{\text {mean }}\right)}{\left[\sum_{i=1}^{n}\left(Y_{i}^{\text {obs }}-Y_{\text {obs }}^{\text {mean }}\right)^{2} \sum_{i=1}^{n}\left(Y_{i}^{\text {sim }}-Y_{\text {sim }}^{\text {mean }}\right)^{2}\right]^{0.5}}\right)^{2}
$$

$$
\text { PBIAS }=\left[\frac{\sum_{i=1}^{n}\left(Y_{i}^{\text {obs }}-Y_{i}^{\text {sim }}\right) \times 100}{\sum_{i=1}^{n}\left(Y_{i}^{\text {obs }}\right)}\right]
$$

$$
\operatorname{RSR}=\left[\frac{\sqrt{\sum_{i=1}^{n}\left(Y_{i}^{\text {obs }}-Y_{i}^{\text {sim }}\right)^{2}}}{\sqrt{\sum_{i=1}^{n}\left(Y_{i}^{\text {obs }}-Y_{o b s}^{\text {mean }}\right)^{2}}}\right]
$$

where, $Y_{i}^{\text {obs }}$ and $Y_{i}^{\text {sim }}$ are the $i^{\text {th }}$ values of observed and simulated flows. Similarly, $Y_{o b s}^{\text {mean }}$ and $Y_{\text {sim }}^{\text {mean }}$ are the mean of observed and simulated flows, respectively and " $n$ " is the total number of observations.

NSE is commonly used to test the model performance whose values range from $-\infty$ to 1 . A model performance is generally accepted as good if the NSE value ranges between 0.5 and $1^{[73]}$. The NSE is utilized in this study as the model performance evaluation because using only $R^{2}$ value could be misleading ${ }^{\text {[74] }}$. The $R^{2}$ ranges from 0 to 1 where a value near 1 represents the strong relationship between observed and simulated output ${ }^{[75]}$. 
PBIAS indicates whether the simulated data is larger or smaller than the observed data. Simulated data having a PBIAS value of 0 is considered perfectly harmonizing with observed data, while a positive or negative value represents the model underestimation or overestimation, respectively. Similarly, RSR is the ratio of the root mean square error (RMSE) and standard deviation of observed data $^{[76]}$. An RSR of " 0 " is considered as the perfect simulated model.

\subsection{Future climate scenarios}

Precipitation and temperature data from ten climate models under RCP 4.5 and 8.5 emission scenarios were obtained from the downscaled CMIP5 phase 5 climate projection archives ${ }^{[77]}$. This archive contains high-resolution translations of climate projections based on different global climate projections from the Coupled Model Intercomparison Project for the contiguous United States. Climate projections available in the archive were developed by using the daily Bias Correction Constructed Analogs (BCCA) downscaled technique ${ }^{[78]}$. In this method, biases between the model simulated output and observed data from the historical period are removed by constructing a linear combination of selected days to produce an analogue, which closely resembles the $\mathrm{GCM}^{[79]}$. The data downloaded from this archive were still associated with bias; therefore, a quantile mapping method was used considering a Gamma distribution for precipitation and normal distribution for temperature to match the cumulative density function of observed and model-simulated data ${ }^{[80]}$

Since we wanted to compare the simulated low flows of the 1988 to 2015 reference period with the future period, flow outputs from every model and each scenario were divided into three equal time intervals: near future (2016-2043), mid-century (2044-2071), and late century (2072-2099).

\subsection{Low-Flow Statistics}

Several methods have been developed to express the low-flow regime of a river. The frequency duration curve (FDC) is one of the most common methods to display the complete range of river discharge from low flows to flood events ${ }^{[7]}$. Other specific low flow indices used in the United States are hydrologically based low flows such as 7-day 10-year low-flow (7Q10) and 1-day 10-year low-flow (1Q10), which are defined as the lowest average flows that occur from seven consecutive days and for one day, respectively, with a recurrence interval of 10 years. The recurrence interval of consecutive day low-flow events was calculated by fitting the annual low-flow series to a log-Pearson Type III distribution (Riggs, 1972). Another method used to examine low flows is a biologically based design flow, which includes: (1) 1B3 (1-day, 3 years) for Criterion Maximum Concentration (CMC), and (2) 4B3 (4-day, 3-year) for Criterion Continuous Concentration (CCC). Additional details about the $\mathrm{CMC}$ and $\mathrm{CCC}$ are provided in previous studies ${ }^{[1,82]}$. In this study, we used the DFLOW tool ${ }^{[83]}$ to calculate hydrologically and biologically based low-flow indices by providing daily discharge simulated from ten climate models and observed records. Other low-flow indices used in this study were annual average 7-day low flows and $95^{\text {th }}$ percentile flow (Q95), which are generally used to assess the stream waste-load assimilative capacity ${ }^{[82]}$.

\section{Results and discussion}

\subsection{SWAT model performance}

The model performance was assessed based on daily and monthly flows at nine USGS gage stations. Average monthly-simulated vs observed flow during the calibration period (2005-2014) and validation period (1995-2004) at the outlet gauge station (USGS 327400) is graphically plotted in Figure 2. The results of statistical indicators used to measure the performance of the model at 9 different gauge stations are given in Table 4 . The performance indicators NSE, $R^{2}$, PBIAS, and RSR for monthly flows at the outlet were found to be $0.86,0.89,2.68 \%$, and 0.38 , respectively during the calibration period. Similarly, the respective performance indicators were $0.83,0.86,0.82 \%$, and 0.41 respectively during the validation period. The overall statistical results for the nine-gauge sites indicate that the SWAT simulated streamflows exceeded the suggested criteria for satisfactory hydrologic modeling results ${ }^{[73]}$.

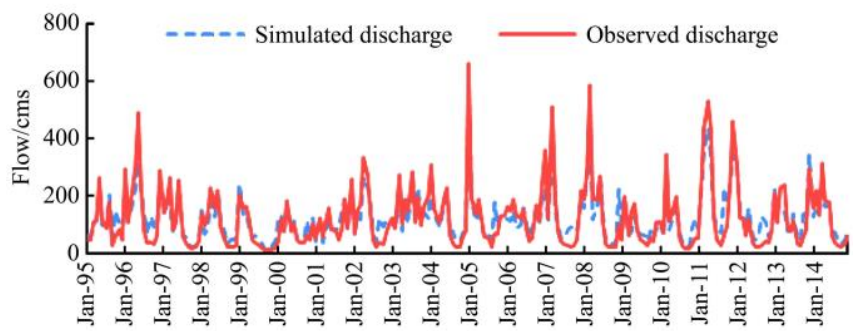

Figure 2 Streamflow calibration (January 2005 to December 2014) and validation (from January 1995 to December 2004) at the watershed outlet (USGS Gauge 03274000)

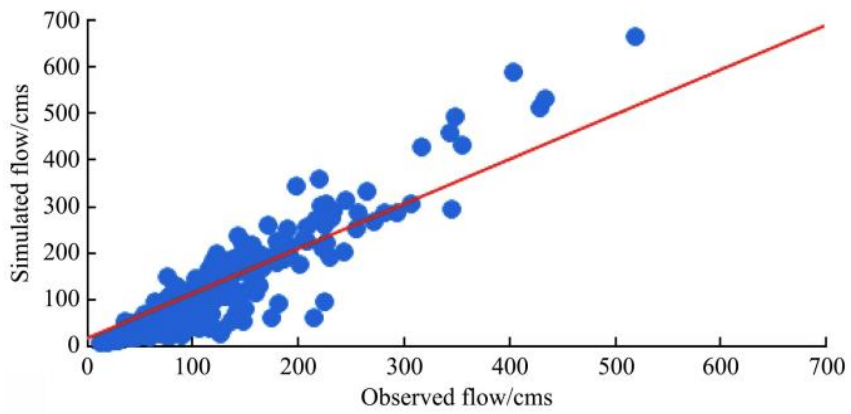

Figure 3 Simulated vs. Observed flow (1:1 ratio) at the outlet of the watershed (USGS Gauge 03274000)

The simulated peak flows during calibration and validation period (Figure 2) were underestimated by the model, which has been commonly reported in previous SWAT studies ${ }^{[84]}$. This may be due to the unequal distribution of meteorological stations within the watershed. For example, the precipitation input in SWAT could be different from the actual precipitation in the watershed due to spatial variability of the precipitation. Nevertheless, based on the performance indicators, the results of the calibrated model can be considered "good" and used for further analysis ${ }^{[73]}$.

\subsection{Climate model evaluation}

We considered 10 climate models, listed in Table 5 based on their performance to replicate the observed precipitation data in the past more accurately. A continuous precipitation dataset from 1980 to 2015 at Dayton International Airport station (00093815) was used to compare projected precipitation from 19 climate models with recorded precipitation for the same period. Even though the correlation of precipitation from all model output at the daily scale was relatively poor with observed records, the monthly scale model outputs exhibited a satisfactory correlation with observed precipitation. The top 10 models that performed well in terms of $R^{2}$ are presented in Table 6 . 
Table 4 Statistical criteria measuring the performance of the model

\begin{tabular}{|c|c|c|c|c|c|c|c|c|c|c|c|}
\hline \multirow{2}{*}{ *Gage stations } & \multirow{2}{*}{ Station name } & \multirow{2}{*}{ Sub-watershed } & \multirow{2}{*}{ Time scale } & \multicolumn{4}{|c|}{ Calibration } & \multicolumn{4}{|c|}{ Validation } \\
\hline & & & & NSE & $R^{2}$ & PBIAS & RSR & NSE & $R^{2}$ & PBIAS & RSR \\
\hline \multirow{2}{*}{3274000} & \multirow{2}{*}{$\begin{array}{l}\text { Great Miami River, } \\
\text { Hamilton }\end{array}$} & \multirow{2}{*}{137} & Monthly & 0.86 & 0.9 & 2.86 & 0.38 & 0.83 & 0.9 & 0.82 & 0.41 \\
\hline & & & Daily & 0.81 & 0.8 & 2.86 & 0.44 & 0.78 & 0.8 & 0.80 & 0.47 \\
\hline \multirow{2}{*}{3272100} & \multirow{2}{*}{$\begin{array}{l}\text { Great Miami River, } \\
\text { Middletown }\end{array}$} & \multirow{2}{*}{126} & Monthly & 0.86 & 0.9 & 4.22 & 0.38 & 0.82 & 0.8 & 0.96 & 0.42 \\
\hline & & & Daily & 0.80 & 0.8 & 4.22 & 0.44 & 0.77 & 0.8 & 0.93 & 0.48 \\
\hline \multirow{2}{*}{3271601} & \multirow{2}{*}{$\begin{array}{l}\text { Great Miami River, } \\
\text { Miamisburg }\end{array}$} & \multirow{2}{*}{116} & Monthly & 0.87 & 0.9 & 1.45 & 0.35 & 0.85 & 0.9 & -0.58 & 0.39 \\
\hline & & & Daily & 0.8 & 0.8 & 1.47 & 0.45 & 0.77 & 0.8 & -0.61 & 0.48 \\
\hline \multirow{2}{*}{3272000} & \multirow{2}{*}{$\begin{array}{l}\text { Twin Creek, } \\
\text { Germantown }\end{array}$} & \multirow{2}{*}{112} & Monthly & 0.79 & 0.8 & 0.87 & 0.45 & 0.77 & 0.8 & 0.8 & 0.48 \\
\hline & & & Daily & 0.66 & 0.7 & 0.94 & 0.58 & 0.63 & 0.7 & 0.76 & 0.61 \\
\hline \multirow{2}{*}{3270500} & \multirow{2}{*}{$\begin{array}{l}\text { Great Miami River, } \\
\text { Dayton }\end{array}$} & \multirow{2}{*}{98} & Monthly & 0.88 & 0.9 & -4.43 & 0.35 & 0.85 & 0.9 & -5.39 & 0.39 \\
\hline & & & Daily & 0.79 & 0.8 & -4.40 & 0.46 & 0.77 & 0.8 & -5.41 & 0.48 \\
\hline \multirow{2}{*}{3266000} & \multirow{2}{*}{$\begin{array}{l}\text { Stillwater River, } \\
\text { Englewood }\end{array}$} & \multirow{2}{*}{84} & Monthly & 0.81 & 0.8 & 4.15 & 0.43 & 0.83 & 0.9 & 5.78 & 0.42 \\
\hline & & & Daily & 0.69 & 0.7 & 4.18 & 0.56 & 0.71 & 0.7 & 5.80 & 0.54 \\
\hline 3263000 & $\begin{array}{l}\text { Great Miami River, } \\
\text { Taylorsville }\end{array}$ & 83 & Daily & 0.75 & 0.8 & -8.46 & 0.5 & 0.74 & 0.7 & -8.24 & 0.51 \\
\hline \multirow{2}{*}{3262700} & \multirow{2}{*}{$\begin{array}{c}\text { Great Miami River, } \\
\text { Troy }\end{array}$} & \multirow{2}{*}{56} & Monthly & 0.84 & 0.9 & -13.95 & 0.4 & 0.8 & 0.9 & -16.93 & 0.45 \\
\hline & & & Daily & 0.75 & 0.8 & -13.98 & 0.5 & 0.74 & 0.8 & -16.91 & 0.51 \\
\hline \multirow{2}{*}{3261500} & \multirow{2}{*}{$\begin{array}{l}\text { Great Miami River, } \\
\text { Sidney }\end{array}$} & \multirow{2}{*}{23} & Monthly & 0.80 & 0.8 & -17.48 & 0.45 & 0.77 & 0.8 & -16.69 & 0.48 \\
\hline & & & Daily & 0.71 & 0.7 & -17.53 & 0.54 & 0.73 & 0.7 & -16.72 & 0.52 \\
\hline
\end{tabular}

Note: * These are USGS gauge stations and the spatial locations are shown in Figure 1.

Table 5 Top 10 GCM models selected for analysis in this study for low flows analysis

\begin{tabular}{lc}
\hline \multicolumn{1}{c}{ Institute } & Model \\
\hline Canadian Centre for Climate Modelling and Analysis, Canada & CanESM2 \\
National Center for Atmospheric Research, USA & CCSM4 \\
Centre National de Recherches Meteorologiques, Meteo-France & CNRM-CM5 \\
Commonwealth Scientific and Industrial Research Organization & CSIRO-Mk3.6.0 \\
NOAA Geophysical Fluid Dynamics Laboratory, USA & GFDL-ESM2M \\
Model for Interdisciplinary Research on Climate, Japan & MIROC5 \\
Model for Interdisciplinary Research on Climate, Japan & MIROC-ESM \\
Max Planck Institute for Meteorology, Germany & MPI-ESM-LR \\
Max Planck Institute for Meteorology, Germany & MPI-ESM-MR \\
Norwegian Climate Center's Earth System Model & NorESM1-M \\
\hline
\end{tabular}

Table $6 R^{2}$ of observed precipitation vs precipitation outputs from climate model under RCP 4.5 for station 00093815 at daily, monthly and annual scale

\begin{tabular}{ccc}
\hline & \multicolumn{2}{c}{$R^{2}$} \\
\cline { 2 - 3 } Climate Models & Daily & Monthly \\
\hline CANSEM2 & 0.00031 & 0.808 \\
CCSM4 & 0.00001 & 0.810 \\
CNRM-CM5 & 0.00013 & 0.760 \\
CSIRO-MK3-6 & 0.00017 & 0.775 \\
GFDL-ESM2M & 0.00006 & 0.759 \\
MIROC5 & 0.00017 & 0.864 \\
MIROC-ESM & 0.00003 & 0.735 \\
MPI-ESM-LR & 0.00025 & 0.838 \\
MPI-ESM-MR & 0.00009 & 0.662 \\
NORESM1-M & 0.00057 & 0.742 \\
\hline
\end{tabular}

Furthermore, the projected precipitation from the 10 different climate models (Table 5) was also compared with the observed baseline precipitation and plotted in Figure 4. During the observed period, the variability of precipitation in the first two quartiles was found to be in a very narrow range of 0 to $1.5 \mathrm{~mm}$ (Figure 4), indicating less variability of rainfall during the observed period. Future precipitation from different models was projected to have a comparatively high variability in the range of 0 to $3.5 \mathrm{~mm}$ for each time span. Similarly, the median value of precipitation in the future from the model output was also found to be higher by approximately $0.6 \mathrm{~mm}$ compared to the observed condition, indicating more precipitation and wetter days can be expected in the future period. This is consistent with the previous research conducted in western Lake Erie Basin of Ohio ${ }^{[85]}$, which reported an increase in annual rainfall in future. Since the poor performance of downscaled CMIP5 precipitation from the 10 models at the daily scale was clearly visible, an additional bias correction of the precipitation data from the selected climate models was carried out prior to further analysis (Figure 5) to narrow down the distribution of future precipitation.

\subsection{Climate change impact on streamflow}

It is important to note that SWAT was set up for an equal number of 28 years and used 3 years of warm-up period in each simulation for a consistent comparison between the 10 GCMs and RCP scenarios. Additionally, the model performance indicators suggested that the model was able to follow the trend of the observed streamflow with reasonable accuracy in the watershed. The low flow parameters including the SWAT-predicted 7-day low flows are directly linked with daily streamflow.

Figure 6 shows the average annual flow in the Great Miami River from the ensemble of 10 climate models for RCP 4.5 and RCP 8.5. The average annual flow under RCP 4.5 was estimated to increase by $25 \%$ in $2016-2043$, followed by a $3.8 \%$ increase in 2044-2071 and $0.3 \%$ increase in 2072-2099, compared to the baseline. On the other hand, under the RCP 8.5 scenario, the average annual flow was projected to increase by $27.5 \%$ in the first period (2016-2043) followed by a 3.8\% increase in mid (2044-2071) with successive increase $(6.6 \%)$ in the late period of $21^{\text {st }}$ century. It was not surprising that the projected increase in streamflow was higher under RCP 8.5 compared to RCP 4.5 as it corresponds to the pathway with the highest greenhouse gas emissions. The previous study conducted in this region also suggests an increasing pattern of low flows in this region (Ohio $)^{[86]}$.

Similarly, outputs from 10 climate models were analyzed for average monthly flow in the watershed as shown in Figure 7. The 
future flow for each month was predicted by SWAT to increase during all three periods as compared to the historical period. A
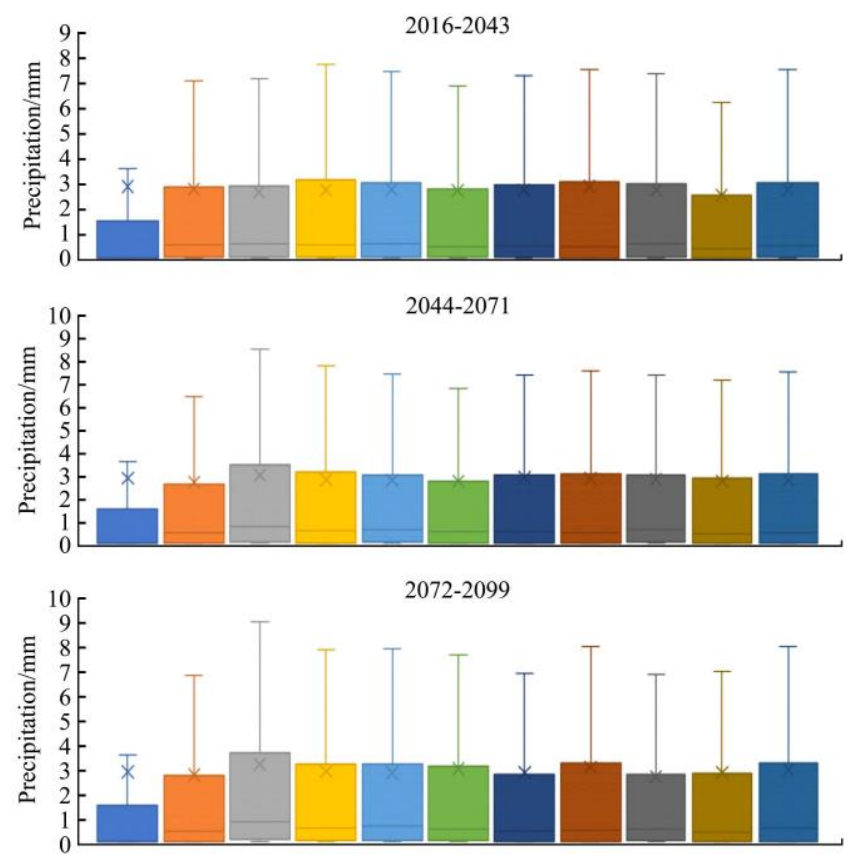

$\square$ OBSERVED (1988-2015) $\square$ MIROC-ESM $\square$ CanEMS2 $\square$ CCSM4 $\square$ CNRM-CM5 $\square$ CSIRO-Mk3.6.0 $\square$ GFDL-ESM2M $\square$ MPI-ESM-MR MIROC5 MPI-ESM-LR NorESM1-M

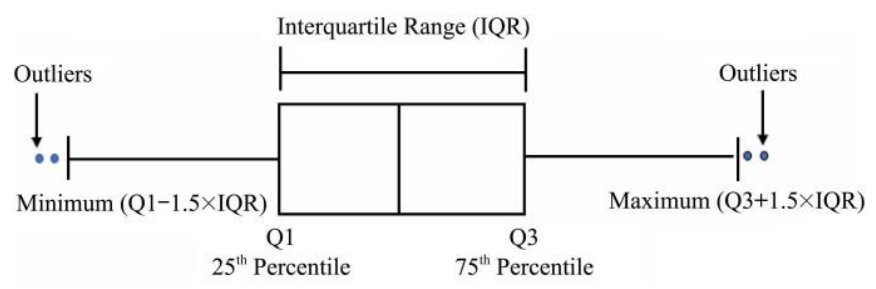

Figure 4 Comparison of daily precipitation data from 10 climate models under RCP 8.5 at three time spans (2016-2043, 2044-2071, and 2072-2099) with observed daily precipitation (1988-2015) data at weather station 0093815 .

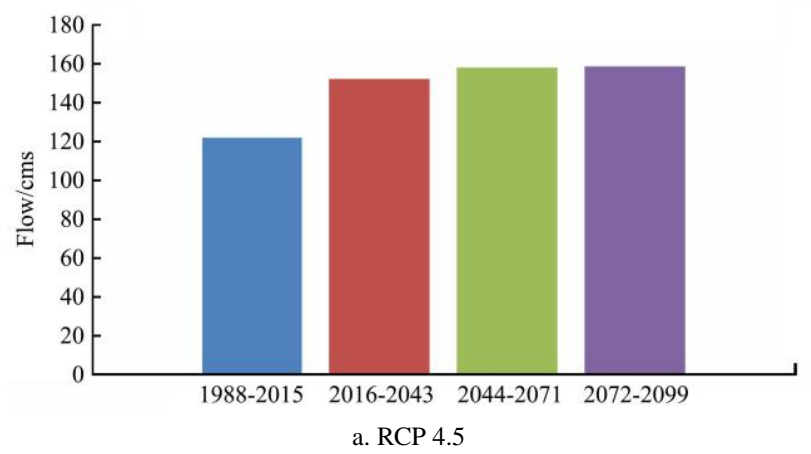

large increase in monthly flow for both RCPs was observed during the summer months
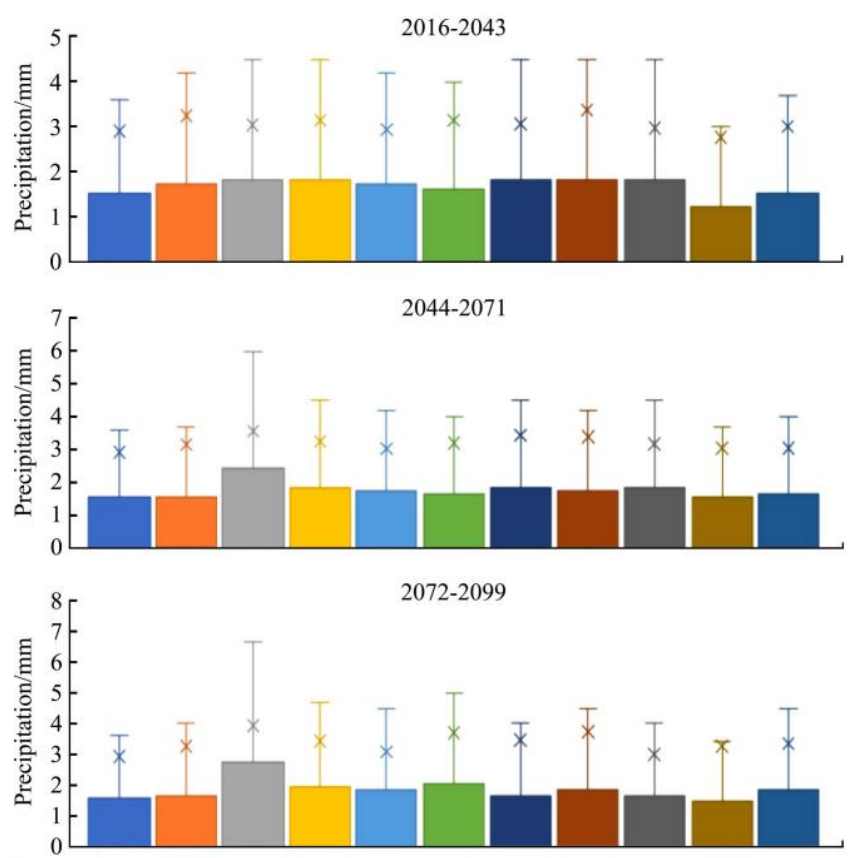

$\square$ OBSERVED (1988-2015) $₫$ MIROC-ESM $\square$ CanEMS2 $\square$ CCSM4 CNRM-CM5 -MIROC5 MPI-ESM-LR NorESM1-M

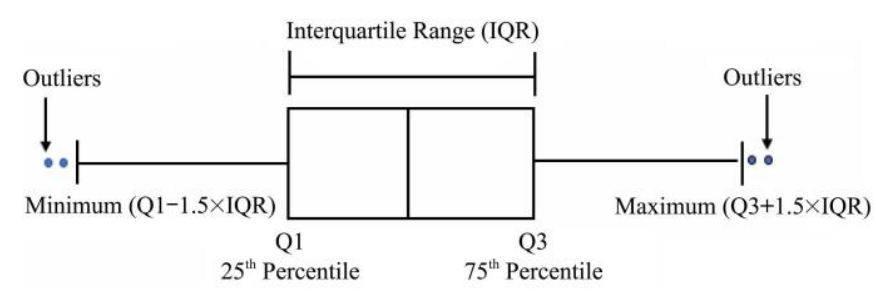

Figure 5 Comparison of precipitation data from 10 climate models under RCP 8.5 after bias correction at three time spans (2016-2043, 2044-2071, and 2072-2099) with observed precipitation data (1988-2015) at climate station 0093815

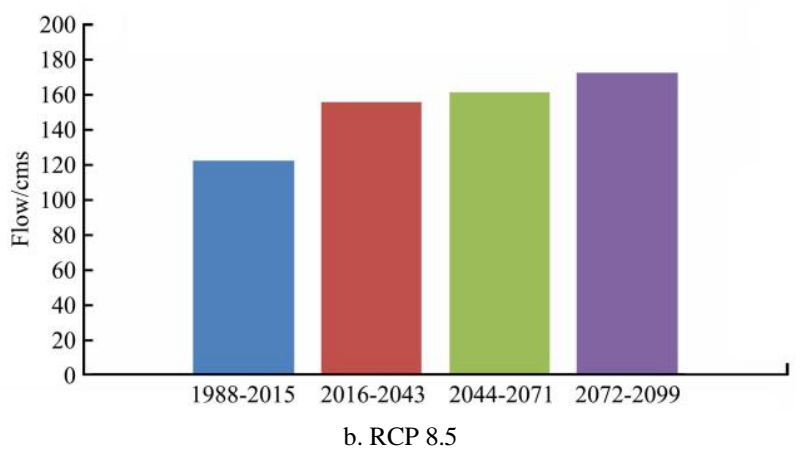

Figure 6 Average annual flow from ensemble of 10 models for RCP 4.5 and RCP 8.5
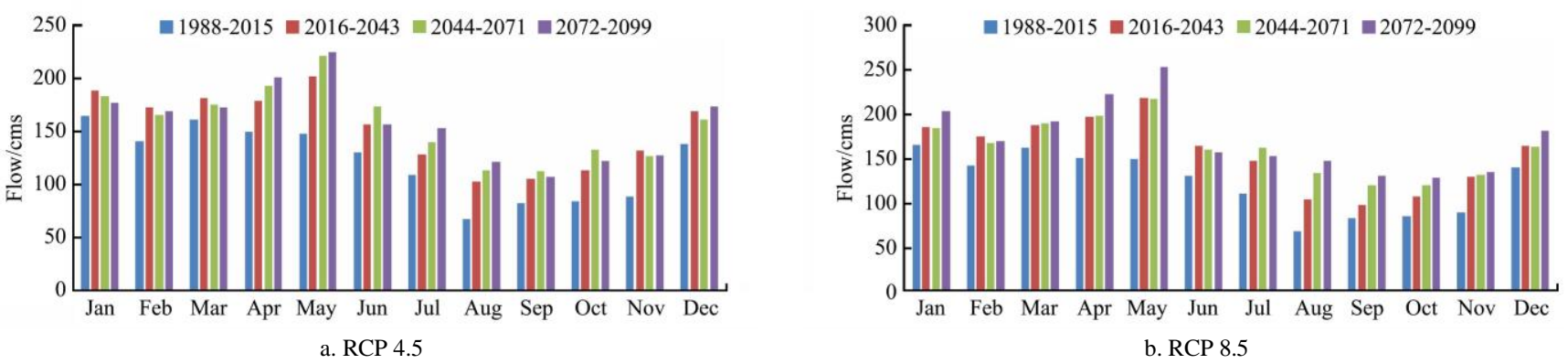

Figure 7 Average monthly flow from ensemble of 10 models for RCP 4.5 and RCP 8.5 


\subsection{Impacts on low flows}

The consecutive seven-day low flow periods simulated from the ensemble of 10 climate models under the two RCP scenarios are summarized using box plots in Figure 8. The results demonstrated that the interquartile range of 7-day low-flows for future years would be smaller than that of past years; however, the median and averages values were found to be increasing in each period. The median 7-day low-flow simulated by the SWAT model for 1988-2015 was found to be $24 \mathrm{~m}^{3} / \mathrm{s}$, which would increase by $16 \%$ in $2016-2043,29 \%$ in $2044-2071$ and $25 \%$ in 2072-2099 under RCP 4.5. Similarly, the median 7-day low-flow value would increase by $16 \%$ in the first century and $25 \%$ in the mid and late century under RCP 8.5 .

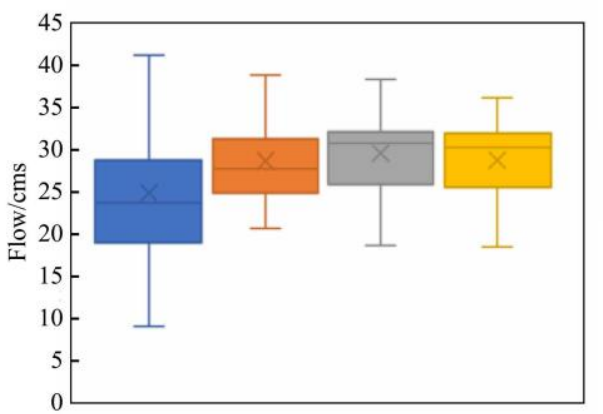

1988-2015

2016-2043

2044-2071

2072-2099

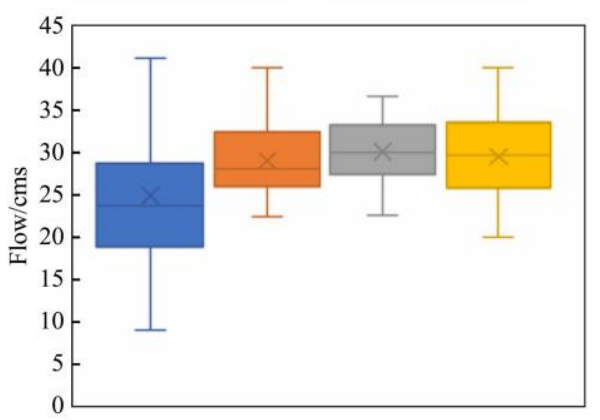

1988-2015

2016-2043

2044-2071

2072-2099

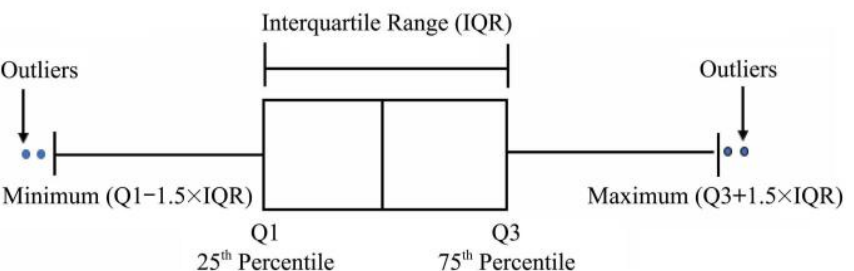

Figure 8 Box plots of annual 7-day low flows from ensemble of 10 climate models

The 7-day low flow simulated by SWAT for each climate model input is presented in Figure 9. Some of the individual models showed an increase in the interquartile range of 7-day low flows during the future periods. As a result, the trends for interquartile and median values within the three periods were not consistent across all GCMs and RCP combinations that were simulated in SWAT.

Figure 10 shows the estimated flow duration curves for the 7-day low flow periods, based on the simulated low flows predicted by SWAT in response to the ensemble of 10 climate models and respective RCP scenarios. The flow duration curves reveal that the 95th percentile low flows (Q95) (i.e., equaled or exceeded 95\% of the time) for the 28 -year simulation period was found to be increasing by $3.9 \%$ and $6.8 \%$ in response to RCP 4.5 and RCP 8.5 , respectively.

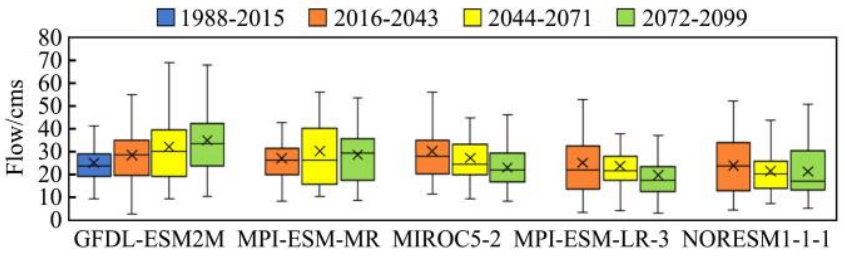

a. RCP 4.5
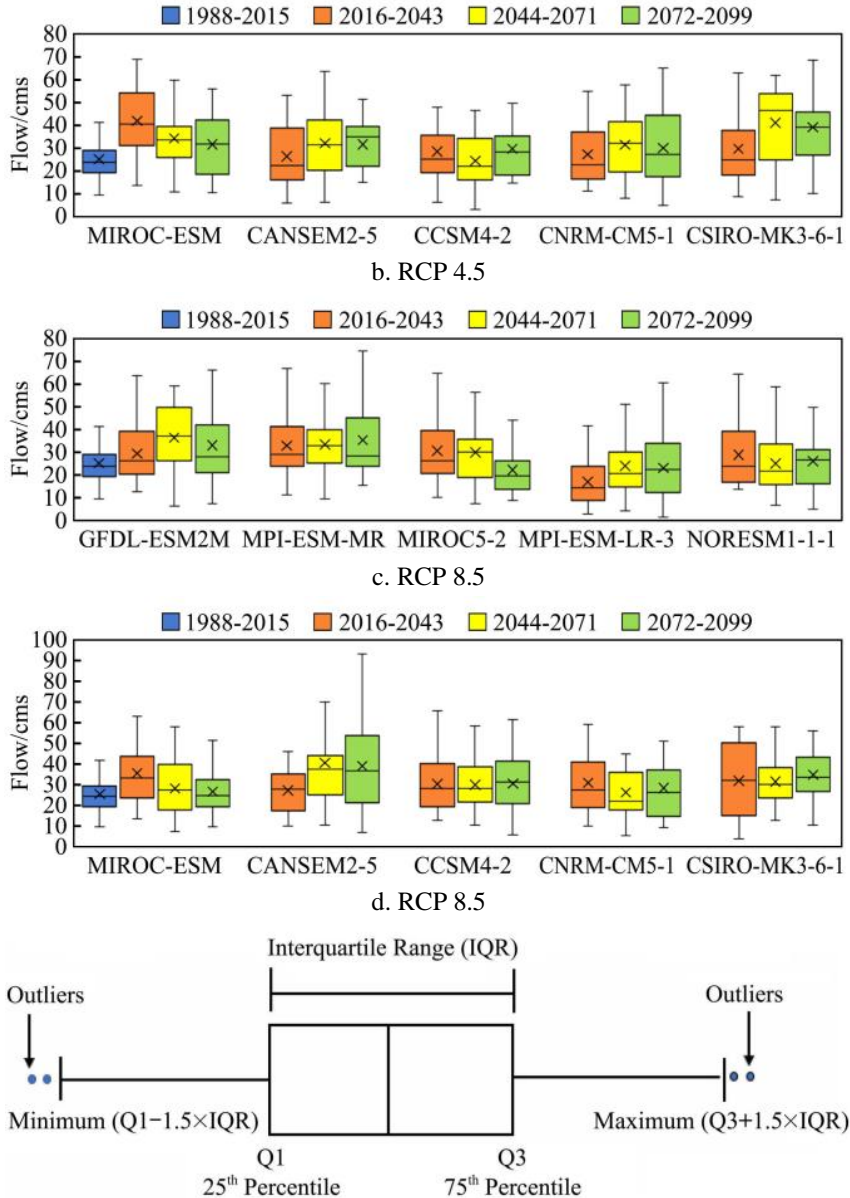

Figure 9 Box and Whisker plots of annual 7-day low flows for 10 different climate models under RCP 4.5 and RCP 8.5 scenarios

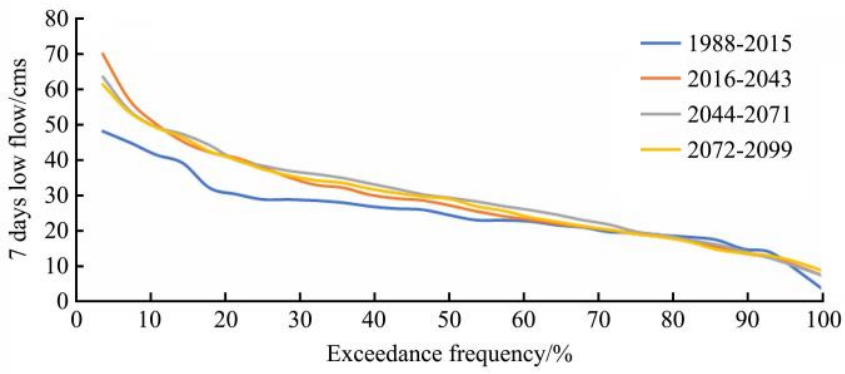

a. $\mathrm{RCP} 4.5$

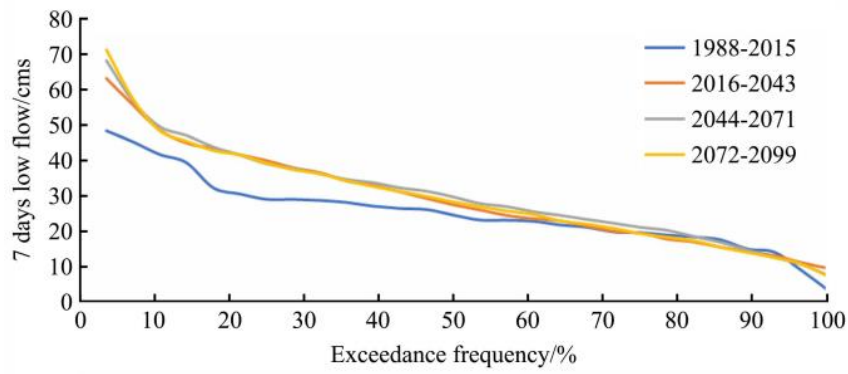

b. RCP 8.5

Figure 10 Flow-duration curves for 7-day low flows from an ensemble of 10 climate models and historical data 


\subsection{Hydrological and biological based low flows}

Hydrological and Biological low flows indices, including 7Q10, 1Q10, 4B3, and 1B3, are essential to evaluate the minimum flows needed in streams to maintain water quality and biological integrity. Figure 11 shows the 7-day 10-year low flows that were predicted by SWAT for each GCM and respective RCP scenario combination. The 7Q10 in 2016-2043 was projected to increase by $9.8 \%$ and continue to increase by $3.8 \%$ in $2044-2071$ and $2.8 \%$ in 2072-2099 compared to the baseline for the RCP 4.5 scenario. Similarly, for RCP 8.5, 7Q10 was expected to increase by $18 \%$ in 2016-2043, plateau in 2044-2071 and then decrease in 2072-2099 by $3 \%$. A similar trend was exhibited for the 1-day 10-year low flows as shown in Figure 12. The main reason for future increased flows was due to the increased projected precipitation, which is a main driving input for the streamflow. While the simulated 7Q10 and 1Q10 values using SWAT were predicted to decrease in the late century, these values were still higher compared to the baseline period (1988-2015).

The biologically based design flows, 4B3 and 1B3, were also calculated based on SWAT simulated flows and are presented in Figures 13 and 14, respectively. The 4B3 and 1B3 flows driven by the ensemble of 10 climate model outputs followed similar trends that were predicted for the 7Q10 and 1Q10 flows, especially in 2016-2043. In 2016-2043 (Figures 13a and 13b), the 4B3 was predicted to increase by $26 \%$, followed by a decrease of $3 \%$ in 2044-2071 and an increase of $11 \%$ in 2072-2099. Similarly, the 4B3 values were predicted to increase in 2016-2043 (32\%), followed by a decrease for 2044-2071 (4.7\%) and then an increase by $2.4 \%$ in 2072-2099, in response to RCP 8.5 (Figure 13). The estimated 1B3 flows also followed similar trends relative to the simulated 4B3 flows during the first two periods of the simulation (Figure 14b). However, the 4B3 flows were predicted to decrease under RCP 8.5 (3\%) and increase under RCP 4.5 (14.7\%) during 2072-2099.
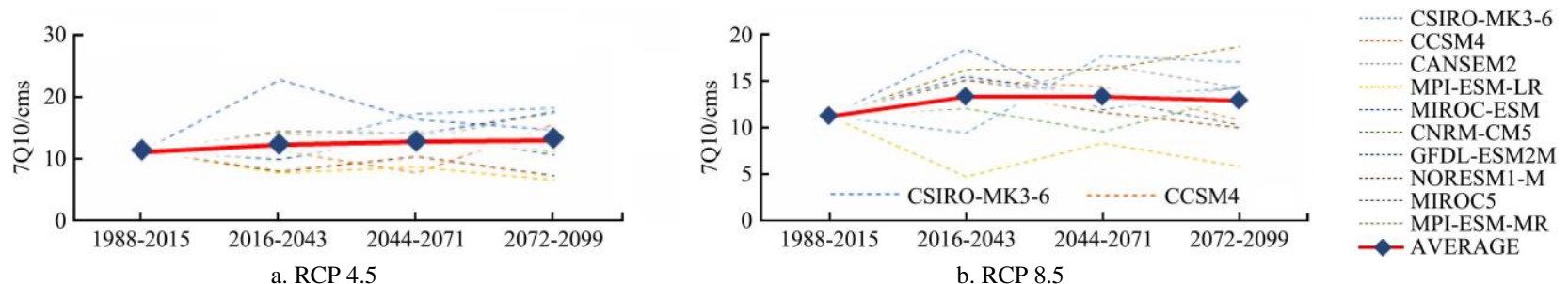

Figure 11 7Q10 low flows from 10 climate models
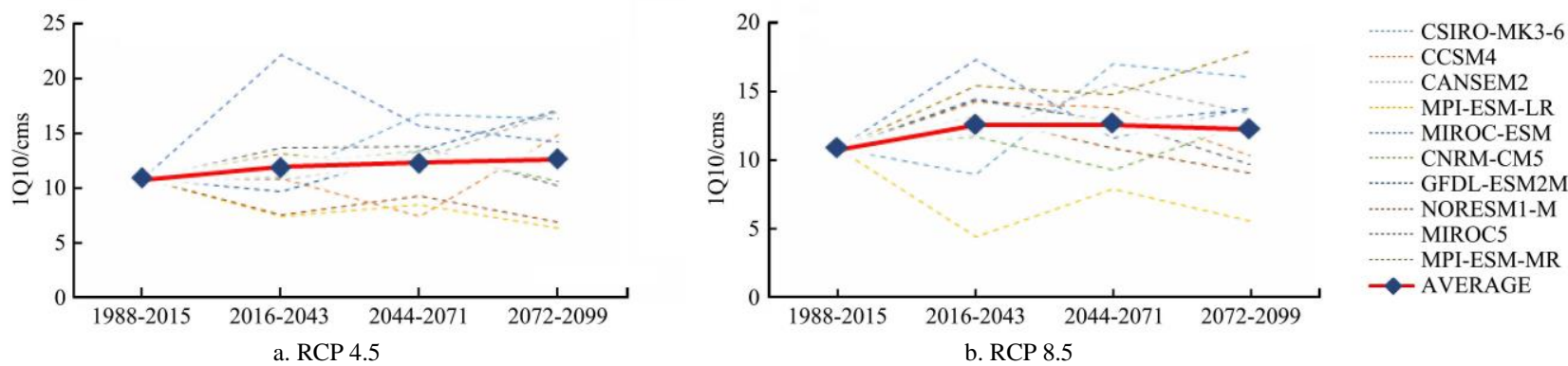

Figure 12 Q10 low flows from 10 climate models
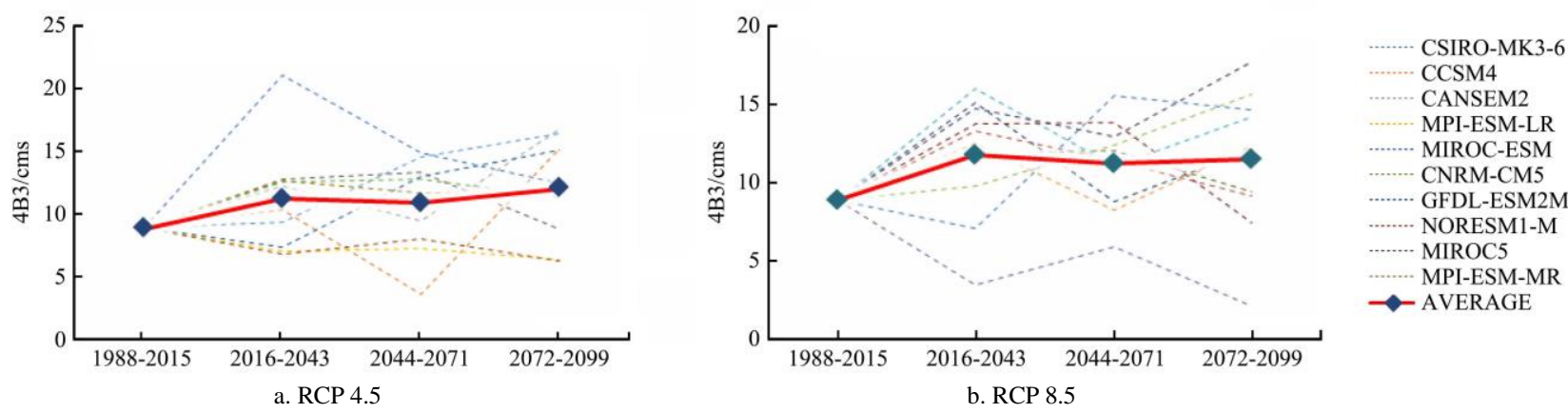

Figure 13 4B3 flows from 10 climate models
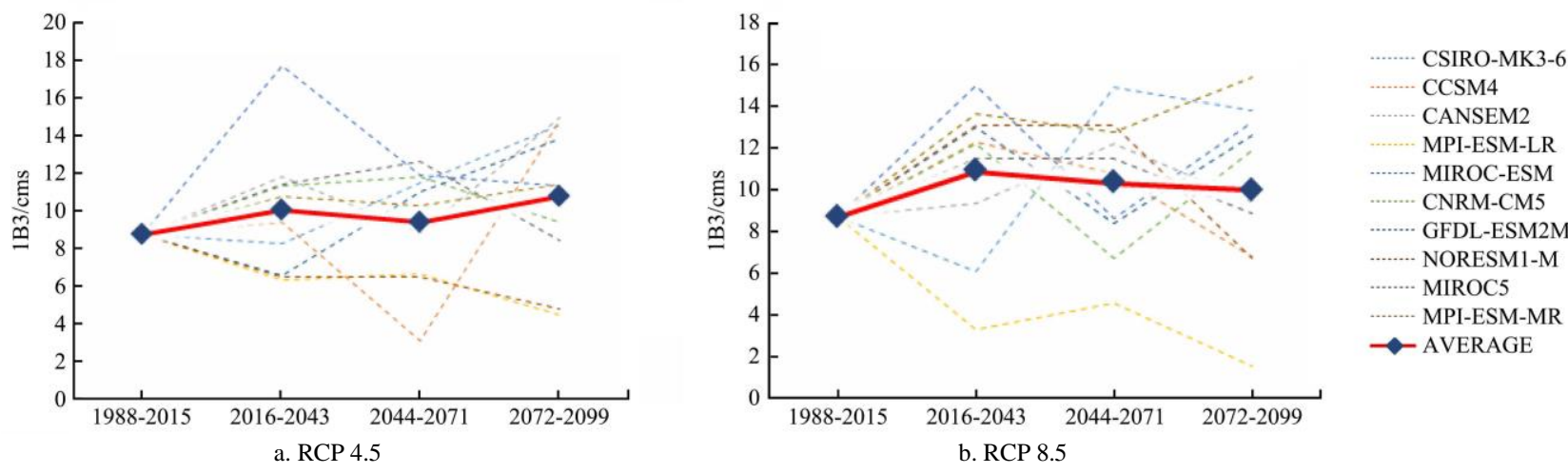

Figure 14 1B3 flows from 10 climate models 
The MPI-ESM-LR model behaved quite differently relative to rest of the climate models that are included in the overall ensemble (Figures 11-14). The SWAT predicted streamflow in response to the MPI-ESM-LR projections showed substantial decreases in low flows for all four indices (7Q10 (37\%), 1Q10 (38.6\%), 4B3 (39.73\%), and 1B3 (48.5\%)) when compared with the baseline. The estimated average annual 1B3 flow in response to RCP 8.5 was predicted to be $3.48 \mathrm{~m}^{3} / \mathrm{s}$ during 2016-2043, which was $60.9 \%$ lower than the 1B3 flow estimated for the historical climate $\left(8.9 \mathrm{~m}^{3} / \mathrm{s}\right)$. However, the predicted MPI-ESM-LR flows increased by $5.9 \mathrm{~m}^{3} / \mathrm{s}$ but then eventually decreased to $2.1 \mathrm{~m}^{3} / \mathrm{s}$ in 2072-2099, which is $76.4 \%$ lower than the baseline period. In contrast, the streamflows predicted by SWAT for the other nine GCMs were higher during 2016-2043, 2044-2071, and 2072-2099 as compared to the historical period.

As the rainfall pattern is expected to increase in the future as indicated in previous literature for this region ${ }^{[85,87]}$, the increased low flows, suggested by this research, will be beneficial for the low flow management in the region. The western corn-belt region of USA relies both on irrigation and rainfed systems, whereas the eastern corn-belt region predominately relies on rain-fed systems ${ }^{[88]}$. However, if this pattern of increased low-flow holds true for the other regions, this might have additional benefit for cropping systems since there is a possibility of more water being available for irrigation during the dry season. This could be very beneficial for regions like the western United States where irrigation is a common practice.

\section{Conclusions}

Projected climate change has the potential to impact the hydrologic cycle in many regions across the globe and affect water resources. Therefore, this study was aimed at investigating the impacts of climate change, especially in terms of low flow regimes in the Great Miami River Watershed, Ohio. In this regard, we set up a hydrological model (SWAT) to generate daily streamflow from the watershed. To estimate future low flows in the watershed, SWAT was run with 10 recently published CMIP5 climate models under two scenarios RCP 4.5 and RCP 8.5 after bias correction. Low flow analyses were conducted at the watershed outlet, where a number of point sources are located. The results showed that the average annual flow would increase throughout the $21^{\text {st }}$ century irrespective of emission scenario as compared with the simulated historical flow. The pattern of future monthly flows depicted that the likelihood of increasing flows during the summer months including May, June, July and August was higher. It was also noted that the average 7-day low flows at the beginning of the $21^{\text {st }}$ century would likely increase by $16 \%$ and remain constant for the later part of the $21^{\text {st }}$ century. The assessment of hydrological and biological low flows indices also reinforced the results of the annual 7-day low flows and predicted an increase in future low flows. The reason for such an increase in low flows could be potentially due to increased rainfall intensity and distribution projected by the climate models. Similarly, all of the GCMs predicted that the trend of hydrologically and biologically based low flows would increase during 2016-2043 and may remain more or less constant or decline slightly thereafter based on the emission scenarios for distinct periods of the $21^{\text {st }}$ century. Regardless, the model simulation results indicated that predicted low flows in the $21^{\text {st }}$ century would not be less than the historical low flows.

The Great Miami River Watershed consists of largely agricultural land with a need for irrigation at some locations for good crop yield. An increasing number of industries and treatment facilities along the river also demand plenty of water in the discharging waterbodies to maintain the integrity of the aquatic ecosystem. Seemingly, an increase in low flows, projected from both scenarios in the waterbodies could enhance the assimilating capacity of the stream but there are other factors such as water temperature, available dissolved oxygen, and characteristics of waste and microorganisms, which could affect the stream assimilative power. Therefore, further research regarding these other factors must be conducted to ensure that water quality goals and biological integrity are maintained in the streams. Although analysis of future climate change with the help of climate models had many limitations, this study, to some extent, can extend our understanding of the climate models and potential impacts associated with climate change in the watershed.

As previous studies reported mixed results about the impact of climate change on low flows, we utilized 10 climate models and two scenarios to evaluate the low flows in the $21^{\text {st }}$ century. The majority of the climate models projected an increase in low flows in the 21 st century, which will have a beneficial effect on the environmental flow and aquatic ecosystem in the watershed and other watersheds in the region. More importantly, increased precipitation and low flows will be beneficial for regions managed with both irrigation and rainfed systems such as the western Corn Belt region and also for areas relying primarily on rainfed systems such as the eastern Corn Belt region. While the CMIP5 data products are widely used for impact analysis of global climate change, the uncertainty associated with future climate predictions are inevitable. Despite acceptable outputs in terms of average values such as monthly and annual flows, the uncertainty increases when estimating extreme flow events such as the low-flow periods reported here. A given GCM needs to be adequately validated for the region where it is being implemented to support water resource management and policy-making. Therefore, further analyses are necessary to develop a better understanding of projected future climate changes for the southwestern Ohio region.

\section{Acknowledgements}

Authors would like to acknowledge the grant support from Office of Research at Youngstown State University to conduct this research.

The authors would also like to acknowledge the corrections and suggestions made by the reviewers, Associate Editor and the Section Editor, Dr. Philip Gassman, to improve this manuscript. The comments from Dr. Gassman were very helpful in addressing numerous issues which were ignored in our initial submission.

\section{[References]}

[1] Haag W R, Warren Jr M L. Effects of severe drought on freshwater mussel assemblages. Trans Amer Fish Soc., 2008; 137(4): 1165-1178.

[2] Gibson J R, Najjar R G. The response of Chesapeake Bay salinity to climate-induced changes in streamflow. Limnol Oceanogr, 2000; 45(8): 1764-1772.

[3] Kundzewicz Z W, Mata L J, Arnell N W, Döll P, Jimenez B, Miller K, et al. The implications of projected climate change for freshwater resources and their management. Hydrolog Sci J. 2008; 3-10.

[4] Moser H, Peter J H, Øivind A, Pierre G, Stephan M, Kathleen W. Impacts of climate change on navigation. In Navigation Seminar following PIANC AGA, 2008.

[5] Saunders III J F, Murphy M, Clark M, Lewis Jr W M. The influence of climate variation on the estimation of low flows used to protect water quality: A nationwide assessment 1. J Am Water Resour As., 2004; 
40(5): 1339-1349.

[6] Burn D H, Buttle J M, Caissie D, MacCulloch G, Spence C, Stahl K. The processes, patterns and impacts of low flows across Canada. Can Water Resour J, 2008; 33(2): 107-124.

[7] Smakhtin V U. Low flow hydrology: a review. J Hydrol., 2001; 240(3-4): 147-86.

[8] Trenberth K E. Conceptual framework for changes of extremes of the hydrological cycle with climate change. In Weather and Climate Extremes, 1999; pp.327-339. Springer, Dordrecht.

[9] Pathak P, Kalra A, Ahmad S, Bernardez M. Wavelet-aided analysis to estimate seasonal variability and dominant periodicities in temperature, precipitation, and streamflow in the Midwestern United States. Water Resour Manag, 2016; 30(13): 4649-65.

[10] Abtew W, Melesse A. Climate change and evapotranspiration. In Evaporation and Evapotranspiration, 2013; pp.197-202. Springer, Dordrecht.

[11] Pachauri R K, Allen M R, Barros V R, Broome J, Cramer W, Christ R, et al. Climate change 2014: synthesis report. Contribution of Working Groups I, II and III to the fifth assessment report of the Intergovernmental Panel on Climate Change, IPCC; 2014.

[12] Tian H, Chen G, Liu M, Zhang C, Sun G, Lu C, et al. Model estimates of net primary productivity, evapotranspiration, and water use efficiency in the terrestrial ecosystems of the southern United States during 1895-2007. Forest Ecol Manag., 2010; 259(7): 1311-1327.

[13] Hayhoe K, Wake C P, Huntington T G, Luo L, Schwartz M D, Sheffield J, et al. Past and future changes in climate and hydrological indicators in the US Northeast. Clim Dynam, 2007; 28(4): 381-407.

[14] Huang S, Krysanova V, Hattermann F. Projection of low flow conditions in Germany under climate change by combining three RCMs and a regional hydrological model. Acta Geophysica, 2013; 61(1): 151-193.

[15] Vaze J, Post D A, Chiew F H, Perraud J M, Viney N R, Teng J. Climate non-stationarity-validity of calibrated rainfall-runoff models for use in climate change studies. J Hydrol, 2010; 394(3-4): 447-457.

[16] Gain A K, Apel H, Renaud F G, Giupponi C. Thresholds of hydrologic flow regime of a river and investigation of climate change impact - the case of the Lower Brahmaputra river Basin. Clim Change, 2013; 120(1-2): 463-75.

[17] Teshager A D, Gassman P W, Schoof J T, Secchi S. Assessment of impacts of agricultural and climate change scenarios on watershed water quantity and quality, and crop production. Hydrol Earth Syst Sc, 2016; 20(8): 3325-3342.

[18] Panagopoulos Y, Gassman P W, Arritt R W, Herzmann D E, Campbell T D, Valcu A, et al. Impacts of climate change on hydrology, water quality and crop productivity in the Ohio-Tennessee River Basin. Int J Agric \& Biol Eng, 2015; 8(3): 29-46.

[19] Wang R, Bowling L C, Cherkauer K A, Cibin R, Her Y, Chaubey I. Biophysical and hydrological effects of future climate change including trends in $\mathrm{CO} 2$, in the St. Joseph River watershed, Eastern Corn Belt. Agr Water Manag, 2017; 180: 280-296

[20] Culbertson A M, Martin J F, Aloysius N, Ludsin S A. Anticipated impacts of climate change on 21st century Maumee River discharge and nutrient loads. J Great Lakes Res., 2016; 42(6): 1332-1342.

[21] Verma S, Bhattarai R, Bosch N S, Cooke R C, Kalita P K, Markus M. Climate change impacts on flow, sediment and nutrient export in a Great Lakes watershed using SWAT. CLEAN-Soil Air Water, 2015; 43(11): 1464-1474.

[22] Cousino L K, Becker R H, Zmijewski K A. Modeling the effects of climate change on water, sediment, and nutrient yields from the Maumee River watershed. J Hydrol Reg Stud., 2015; 4: 762-775.

[23] Arnell N W. Effects of IPCC SRES* emissions scenarios on river runoff: a global perspective. Hydrol Earth Syst Sc Dis, 2003; 7(5): 619-641.

[24] Takle E S, Gutowski W J, Arritt R W, Pan Z, Anderson C J, Da Silva R R, et al. Project to intercompare regional climate simulations (PIRCS): description and initial results. J Geophys Res-Atmos, 1999; 104(D16): 19443-19461.

[25] Rinke A, Dethloff K, Cassano J J, Christensen J H, Curry J A, Du P, et al. Evaluation of an ensemble of Arctic regional climate models: spatiotemporal fields during the SHEBA year. Clim Dynam, 2006; 26(5): 459-472.

[26] Mohammed I N, Bomblies A, Wemple B C. The use of CMIP5 data to simulate climate change impacts on flow regime within the Lake Champlain Basin. J Hydrol Reg Stud., 2015; 3: 160-186.
[27] Middelkoop H, Daamen K, Gellens D, Grabs W, Kwadijk J C, Lang H, et al. Impact of climate change on hydrological regimes and water resources management in the Rhine basin. Clim Change, 2001; 49(1-2): 105-128.

[28] Shabalova M V, Van Deursen W P, Buishand T A. Assessing future discharge of the river Rhine using regional climate model integrations and a hydrological model. Clim Res, 2003; 23(3): 233-246.

[29] Unawardhana L N, Kazama S. A water availability and low-flow analysis of the Tagliamento River discharge in Italy under changing climate conditions. Hydrol Earth Syst Sc., 2012; 16(3): 1033-1045.

[30] Gain A K, Immerzeel W W, Sperna Weiland F C, Bierkens M F. Impact of climate change on the stream flow of the lower Brahmaputra: trends in high and low flows based on discharge-weighted ensemble modelling. Hydrol Earth Syst Sc., 2011; 15(5): 1537-1545.

[31] Small D, Islam S, Vogel R M. Trends in precipitation and streamflow in the eastern US: Paradox or perception? Geophys Res Lett, 2006; 33(3).

[32] Schoen M E, Small M, DeKay M L, Casman E, Kroll C. Effect of climate change on design-period low flows in the Mid-Atlantic US. In World Environmental and Water Resources Congress 2007: Restoring Our Natural Habitat, 2007; pp.1-14.

[33] Mahmood R, Jia S, Babel M S. Potential impacts of climate change on water resources in the Kunhar River Basin, Pakistan. Water, 2016; 8(1): 23.

[34] Cervi F, Petronici F, Castellarin A, Marcaccio M, Bertolini A, Borgatti L. Climate-change potential effects on the hydrological regime of freshwater springs in the Italian Northern Apennines. Sci Total Environ, 2018; 622:337-348.

[35] Marx A, Kumar R, Thober S, Rakovec O, Wanders N, Zink M, et al Climate change alters low flows in Europe under global warming of 1.5, 2, and $3^{\circ} \mathrm{C}$. Hydrol Earth Syst Sc, 2018; 22(2): 1017-1032.

[36] Kreye P, Woerner V, Gelleszun M, Meon G. Model based projection of changes in low flow situations due to climate change in the federal state of Lower Saxony. Hydrol Wasserbewirts, 2017; 61(4): 217-231.

[37] Stumbaugh M, Hamlet A F. Effects of climate change on extreme low-flows in small lowland tributaries in the Skagit River Basin. Northwest Sci., 2016; 90(1): 44-56.

[38] Dang Q T, Laux P, Kunstmann H. Future high-and low-flow estimations for Central Vietnam: a hydro-meteorological modelling chain approach. Hydrol Sci J., 2017; 62(11): 1867-1889.

[39] Mozayyan M, Akhoond Ali A M, Massah Bavani A R, Radmanesh F, Gohari A. Impacts of Climate Change on Low Flows at Tang Panj Sezar Subbasin, Southwest of Iran. J Hydrol Eng, 2017; 22(11): 05017021.

[40] Parry M. Scenarios for climate impact and adaptation assessment. Glob Environ Change, 2002; 12: 149-153.

[41] Tian Y, Xu Y P, Ma C, Wang G. Modeling the impact of climate change on low flows in Xiangjiang River Basin with Bayesian averaging method. J Hydrol Eng., 2017; 22(9): 04017035.

[42] Laaha G, Parajka J, Viglione A, Koffler D, Haslinger K, Schöner W, et al. A three-pillar approach to assessing climate impacts on low flows. Hydrol Earth Syst Sc, 2016; 20(9): 3967-3985.

[43] Kay A L, Bell V A, Guillod B P, Jones R G, Rudd A C. National-scale analysis of low flow frequency: historical trends and potential future changes. Clim Change, 2018; 147(3-4): 585-599.

[44] Moss R H, Edmonds J A, Hibbard K A, Manning M R, Rose S K, van Vuuren D P, et al. The next generation of scenarios for climate change research and assessment. Nature, 2010; 463(7282): 747.

[45] Van Vuuren D P, Edmonds J, Kainuma M, Riahi K, Thomson A, Hibbard $\mathrm{K}$, et al. The representative concentration pathways: an overview. Clim Change, 2011; 109(1-2): 5.

[46] Arnold J G, Srinivasan R, Muttiah R S, Williams J R. Large area hydrologic modeling and assessment part I: model development 1 . J Am Water Resour As, 1998; 34(1): 73-89.

[47] Zuo D, Xu Z, Zhao J, Abbaspour K C, Yang H. Response of runoff to climate change in the Wei River basin, China. Hydrol Sci J., 2015; 60(3): 508-522.

[48] Babur M, Babel M S, Shrestha S, Kawasaki A, Tripathi N K. Assessment of climate change impact on reservoir inflows using multi climate-models under RCPs - The case of Mangla Dam in Pakistan. Water, 2016; 8(9): 389.

[49] Mohammed K, Saiful Islam A K, Tarekul Islam G M, Alfieri L, Bala S K, Uddin Khan M J. Impact of high-end climate change on floods and low flows of the Brahmaputra River. J Hydrol Eng., 2017; 22(10): 04017041.

[50] Eisner S, Flörke M, Chamorro A, Daggupati P, Donnelly C, Huang J, et al. 
An ensemble analysis of climate change impacts on streamflow seasonality across 11 large river basins. Clim Change, 2017; 141(3): 401-17.

[51] $\mathrm{Xu} \mathrm{H}$, Luo Y. Climate change and its impacts on river discharge in two climate regions in China. Hydrol Earth Syst Sc, 2015; 19(11): 4609-4618.

[52] Piniewski M, Szcześniak M, Kundzewicz Z W, Mezghani A, Hov Ø. Changes in low and high flows in the Vistula and the Odra basins: Model projections in the European-scale context. Hydrol Process, 2017; 31(12): 2210-2225.

[53] Leta O, El-Kadi A, Dulai H. Impact of climate change on daily streamflow and its extreme values in pacific island watersheds. Sustainability, 2018; 10(6): 2057.

[54] Hwang S, Graham W D. Assessment of alternative methods for statistically downscaling daily GCM precipitation outputs to simulate regional streamflow. J Am Water Resour As, 2014; 50(4): 1010-1032.

[55] Pal I, Towler E, Livneh B. How can we better understand low river flows as climate changes. Eos (Washington. DC), 2015; 96.

[56] Ayers J, Ficklin D L, Stewart I T, Strunk M. Comparison of CMIP3 and CMIP5 projected hydrologic conditions over the Upper Colorado River Basin. Int J Climatol, 2016; 36(11): 3807-3818.

[57] Jothityangkoon C, Sivapalan M, Farmer D L. Process controls of water balance variability in a large semi-arid catchment: downward approach to hydrological model development. J Hydrol, 2001; 254(1-4): 174-198.

[58] Taylor K E, Stouffer R J, Meehl G A. An overview of CMIP5 and the experiment design. B Am Meteorol Soc, 2012; 93(4): 485-498.

[59] Meehl G A, Moss R, Taylor K E, Eyring V, Stouffer R J, Bony S, et al. Climate model intercomparisons: Preparing for the next phase. Eos, Transactions American Geophysical Union., 2014; 95(9): 77-78.

[60] Wilby R L, Harris I. A framework for assessing uncertainties in climate change impacts: Low-flow scenarios for the River Thames, UK. Water Resour Res, 2006; 42(2).

[61] Jenkins G, Lowe J. Handling uncertainties in the UKCIP02 scenarios of climate change. Hadley Centre, Technical note 44, Exeter, UK. 2003.

[62] OEPA. Ohio Environmental Protection Agency. Total Maximum Daily Loads for the Mad River Watershed, 2009.

[63] Neitsch S L, Arnold J G, Kiniry J R, Williams J R. Soil and water assessment tool theoretical documentation version 2009. Texas Water Resources Institute, 2011.

[64] Johnson R R. An investigation of curve number applicability to watersheds in excess of 25000 hectares $\left(250 \mathrm{~km}^{2}\right)$. J Environ Hydrol, 1998; 6(10).

[65] DEM. Digital elevation model. http://www.seamless.usgs.gov Accessed on [2010-01-10].

[66] NLCD. National Land Cover Dataset. National landcover data set. http://www.epa.gov/mrlc/nlcd-2011.html Accessed on [2010-01-05].

[67] USDA-NRCS (U.S. Department of Agriculture-Natural Resources Conservation Service). Soil Survey Geographic (SSURGO) Database. 2005. http://www.ncgc.nrcs.usda.gov/products/datasets/ssurgo/ index.html. Accessed on [2010-01-10].

[68] Winchell M, Srinivasan R, Di Luzio M, Arnold J. ArcSWAT interface for SWAT2012: user's guide. Blackland Research and Extension Center, Texas Agrilife Research. Grassland. Soil and Water Research Laboratory, USDA Agricultural Research Service, Texas, 2013; 3.

[69] National Climatic Data Center, 2011. Climate data online. https://www.ncdc.noaa.gov/oa/ncdc.html. Accessed on [2010-01-10].

[70] Enforcement, E.P.A., Compliance History Online Metadata, 2015. https://edg.epa.gov/metadata/catalog/search/resource/details.page?uuid=\%7 B5DF97189-37B4-421E-B74C-C225EECC423F\%7D. Accessed on
[2010-01-10].

[71] Abbaspour K C, Vejdani M, Haghighat S, Yang J. SWAT-CUP calibration and uncertainty programs for SWAT. In MODSIM 2007 International Congress on Modelling and Simulation, Modelling and Simulation Society of Australia and New Zealand, 2007; pp.1596-1602.

[72] Sharma S, Srivastava P, Fang X, Kalin L. Incorporating climate variability for point-source discharge permitting in a complex river system. T ASABE, 2012; 55(6): 2213-2228.

[73] Moriasi D N, Gitau M W, Pai N, Daggupati P. Hydrologic and water quality models: Performance measures and evaluation criteria. T ASABE 2015; 58(6): 1763-1785.

[74] Krause P, Boyle D P, Bäse F. Comparison of different efficiency criteria for hydrological model assessment. Adv Geosciences, 2005; 5: 89-97.

[75] Santhi C, Srinivasan R, Arnold J G, Williams J R. A modeling approach to evaluate the impacts of water quality management plans implemented in a watershed in Texas. Environ Modell Softw, 2006; 21(8): 1141-1157.

[76] Singh J, Knapp H V, Arnold J G, Demissie M. Hydrological modeling of the Iroquois river watershed using HSPF and SWAT 1. J Am Water Resour As., 2005; 41(2): 343-360.

[77] Brekke L, Thrasher B L, Maurer E P, Pruitt T. Downscaled CMIP3 and CMIP5 climate and hydrology projections: Release of downscaled CMIP5 climate projections, comparison with preceding information, and summary of user needs. US Dept. of the Interior, Bureau of Reclamation, Technical Services Center, Denver, 2013.

[78] Maurer E P, Hidalgo H G. Utility of daily vs. monthly large-scale climate data: an intercomparison of two statistical downscaling methods. Hydrol Earth Syst Sc Discussions, 2007; 4(5): 3413-3440.

[79] Hwang S, Graham W D. Development and comparative evaluation of a stochastic analog method to downscale daily GCM precipitation. Hydrol Earth Syst Sc, 2013; 17(11): 4481-4502.

[80] Maurer E P, Ficklin D L, Wang W. Technical Note: The impact of spatial scale in bias correction of climate model output for hydrologic impact studies. Hydrol Earth Syst Sc Discussions, 2016; 20: 685-696.

[81] Dilks D W, Freedman P L, Monson B A. Technical guidance manual for performing waste load allocations, 1992.

[82] Stephan C E, Mount D I, Hansen D J, Gentile J H, Chapman G A, Brungs W A. Guidelines for deriving numerical national water quality criteria for the protection of aquatic organisms and their uses. Washington, DC: US Environmental Protection Agency; 1985.

[83] Rossman L A. DFLOW user's manual. 1990. Available at https://nepis.epa.gov/Exe/ZyPURL.cgi?Dockey=30001JEH.TXT Accessed on [2010-01-10].

[84] Gassman P W, Sadeghi A M, Srinivasan R. Applications of the SWAT model special section: Overview and insights. J Environ Qual., 2014; 43(1): 1-8.

[85] Pease L A, Fausey N R, Martin J F, Brown L C. Projected climate change effects on subsurface drainage and the performance of controlled drainage in the Western Lake Erie Basin. J Soil Water Conserv, 2017; 72(3): 240-250.

[86] Douglas E M, Vogel R M, Kroll C N. Trends in floods and low flows in the United States: impact of spatial correlation. J Hydrol., 2000; 240(1-2): 90-105.

[87] Cousino L K, Becker R H, Zmijewski K A. Modeling the effects of climate change on water, sediment, and nutrient yields from the Maumee River watershed. J Hydrol., 2015; 4: 762-775.

[88] Green T R, Kipka H, David O, McMaster G S. Where is the USA Corn Belt, and how is it changing? Science of the Total Environment, 2017; 618: 1613-1618. 